Rodrigo Moreno Marques:

\title{
Polarization of information and knowledge: a dialectical approach
}

\begin{abstract}
:
This article discusses the polarization of information and knowledge, a phenomenon that is increasingly relevant in different spheres of the contemporary socioeconomic dynamics. According to this notion, founded mainly on the works of Karl Marx, information and knowledge are central elements in the contradictions between capital and labour, as well as in the internal contradictions of the working class. The idea of polarization of information and knowledge offers a critical point of view against the authors who, while trying to grasp the socioeconomic dynamics of our times, are captured by the enchantment of the techno-scientific progress. The article also adopts the Marxian concepts of universal labour and general intellect to argue that information, knowledge, and science are social constructions built collectively and should be treated as common goods. However, currently, the emancipatory perspective of the general intellect envisioned by Marx has been replaced by an opposite tendency: the private appropriation of the general intellect.
\end{abstract}

\section{Agenda:}

Introduction

Polarization of information and knowledge between capital and labour

Polarization of information and knowledge within the working class

Towards the private appropriation of the general intellect?

\section{Author:}

Prof. Dr. Rodrigo Moreno Marques:

- Universidade FUMEC, Belo Horizonte (MG), Brazil

- $\quad$ - 55) 31 99652-9027, $ه$ rodrigo.marques@fumec.br, 品 http://lattes.cnpq.br/4390865555343440

- Relevant publications:

- Marques, Rodrigo Moreno. Trabalho, informação e conhecimento: relendo Marx na era da informação. Logeion: Filosofia da Informação, 2 (1), 47-71, 2015.

- Marques, Rodrigo Moreno; Kerr Pinheiro, Marta Macedo. Cognitive capitalism or polarization of knowledge? Voices from Silicon Valley unveil myths of the information age. In: III Journées Scientifiques Internationales du Réseau MUSSI, Toulouse (France), v. III, 155-172, 2016. 


\section{Introduction}

The socialism advocated by Karl Marx was not based on a subjective moral demand, but on a theory of history that is dialectically set in motion by its internal contradictions. Following Hegel's critique of moralism, in Marx's theoretical framework the subjective moral demand becomes powerless in comparison with his insight into history, which is pictured as a movement towards the realization of a better and more humane social order. Although Marx's political economy was not conceived to be a moral judgment of the capitalist mode of production, his description of the negative consequences of capitalism embodies moral valuations. These negative aspects are recognized as historically necessary steps for the historical progress (Fetscher 1991). The rising of socialism would make, according to Marx (1853), "human progress cease to resemble that hideous pagan idol, who would not drink nectar but from the skulls of the slain".

For Marx, overcoming of the capitalist mode of production requires unveiling commodity fetishism, which would reveal the social relations of production between the owners of the means of production and owners of labour power. The historical process by which capitalism is overcome will be determined by the contradictions between the forces of production and the social relations of production. As a result of this dialectical perspective of history, a transformation is expected to occur in the way society distributes the value and the surplus value produced by the working class. The understanding of capitalist contradictory dynamics would enable the proletariat to accelerate the historical process of emancipating the human being or, in Marx's terms, to "shorten and lessen the birth-pangs" of a new society (Marx 1996 [1867], p.10).

These considerations provide the background to the question that drives the exposition presented in this article: What is the role of information and knowledge in a Marxist perspective of overcoming the capitalist mode of production?

In this article, I argue that overcoming capitalism will require the abolishment of the polarization of information and knowledge, a phenomenon that is increasingly relevant in different spheres of the contemporary socioeconomic dynamics. According to this perspective, information and knowledge are central elements not only in the contradictions between capital and labour, but also in the internal contradictions of the working class. In different realms of society, the asymmetric distribution of information and knowledge can be a source of socioeconomic inequality or an instrument for exploitation. Although Marx did not adopt the expression 'polarization of information and knowledge', this idea is, from my perspective, clearly present in some of his most important works, such as in Capital (1996 [1867]) as well as in the manuscripts Theories of Surplus Value (1994a [1863]) and Chapter Six - Results of the Direct Production Process (1994b [1864]).

The idea of polarization of information and knowledge offers a critical point of view against authors who, while trying to grasp the socioeconomic dynamics of the twenty-first century, are captured by the enchantment of the techno-scientific progress. The optimistic description of the contemporary society presented by André Gorz exemplifies this kind of misconception:

[The] "main productive force, knowledge, is a product that is [...], to a large extent, 'general intelligence', shared culture, living and lived practical knowledge. It has no exchange-value, which means that it can, in theory, be shared at will, as anyone and everyone sees fit, at no charge, particularly on the Internet. But the fact is that the portion of knowledge that is not originally shared and common, namely formalized propositional knowledge - detachable from its producers and existent only because it has been formally produced - is also potentially free, since it can be reproduced in unlimited quantities and shared without having to pass through the value-form (money). It is, moreover, generally accessible, at least in theory, thanks to the Internet, which means that the main productive force and the main source of value can for the first time be put potentially beyond private appropriation" (Gorz 2010, p. 52-53).

Gorz's analysis falls into the trap of technological determinism since his misleading optimism about the Internet prevents him to realize the contradictions of the so-called information society. According to this frequent type of misunderstanding, the Internet and the contemporary sociotechnical networks are supposed to allow unlimited sharing of information and knowledge, which are taken as elements that can flow without any 
restriction and cannot be privately appropriated. Contrary to this beautified discourse, I advocate that the analysis of the role of information and knowledge in the current socioeconomic dynamics requires firstly the recognition of the contradictory essence of information and knowledge.

The article is divided into five sections. After this introduction, the two next sections present the main arguments of the polarization of information and knowledge approach. According to the first one, from the early days of capitalism to present, information and knowledge have been central elements in the contradictions between capital and labour. This position draws from a historical perspective built upon the works of Mandeville (1792), Babbage (1832), Marx (1994a, 1994b, 1996), Taylor (1911), and Braverman (1998). The second key argument states that information and knowledge have a fundamental role not only in the contradictions between capital and labour, but also in the contradictions within the working class. This argument is founded on the works of Braverman (1998), Rubin (1972) and Marx (1994b, 1996). In the fourth section, I use the Marxian concepts of "universal labour" (1998) and "general intellect" (1987) to argue that knowledge and science are social constructions built collectively and should be treated as common goods. However, I conclude that currently, the emancipatory potential of the general intellect as conceived by Marx has been replaced by an opposite tendency: the private appropriation of the general intellect.

\section{Polarization of information and knowledge between capital and labour}

The idea of polarization of information and knowledge draws from a historical perspective to sustain the first key argument: from the early days of capitalism to present, information and knowledge have been central elements in the contradictions between capital and labour.

Since the 18th century, when the capitalist mode of production was born, the adoption of information and knowledge as instruments of domination or emancipation has become a strong tendency, not only in the workplace but also in broader social spheres. Throughout its history, capitalism has not demonstrated any commitment to the universalization of information, knowledge or science. Capital has certainly a progressive character, but not a reputation of being an educating force for the working class. On the contrary, in capitalism, the production processes are conducted in an arena where workers struggle against capitalists to dominate and control the use of information and knowledge.

The words of Mandeville (1732) reveals how the ideology of the emerging bourgeois was very explicit in the early days of capitalism. His prescription about what kind of knowledge should be accessible to workers was based on restrictive and functional criteria. According to him, workers' education and instruction should be limited to the skills that were useful to their labour. Any other kind of knowledge was considered harmful and dangerous to society. In his terms:

"To make the society happy and people easy under the meanest circumstances, it is requisite that great numbers of them should be ignorant as well as poor. Knowledge both enlarges and multiplies our desires [...] The welfare and felicity therefore of every State and Kingdom, require that the knowledge of the working poor should be confined within the verge of their occupations, and never extended (as to things visible) beyond what relates to their calling. The more a shepherd, a plowman or any other peasant knows of the world, and the things that are foreign to his labour or employment, the less fit he will be to go through the fatigues and hardships of it with cheerfulness and content. Reading, writing and arithmetic are very necessary to those whose business requires such qualifications, but where people's livelihood has no dependence on these arts, they are very pernicious to the poor" (Mandeville 1732, p. 288).

Expanding Adam Smiths' thoughts, Sir Charles Babbage, the pioneer proponent of the "division of mental labour" (Babbage 1832, p. 191), recommended that the division of work in industries should be conceived with the aim of minimizing the skills workers would require to conduct the labour processes, in order to increase child labour and, consequently, reduce wages. 
"The facility of acquiring skill in a single process, and the early period of life at which it can be made a source of profit, will induce a greater number of parents to bring up their children to it; and from this circumstance also, the number of workmen being increased, the wages will soon fall" (Babbage 1832, pp. 170-171).

Although Marx emphasises the importance of knowledge in the capitalist production process, he also highlights that the fractioning of the labour process institutes a social organisation of work that deforms the workers, imprisoning each one of them in a fraction of their profession. Hence, the collective labourer that constitutes the live mechanism of manufacturing is based on a partial and limited kind of worker, characterised by Marx as a "crippled monstrosity" (1996, p. 365). Thus, the intellectual forces of the production process become contradictory forces against the partial worker, and scientific knowledge becomes a force that benefits capital instead of the working class.

"Intelligence in production expands in one direction, because it vanishes in many others. What is lost by the detail labourers is concentrated in the capital that employs them. It is a result of the division of labour in manufactures, that the labourer is brought face to face with the intellectual potencies of the material process of production, as the property of another, and as a ruling power. This separation begins in simple cooperation, where the capitalist represents to the single workman, the oneness and the will of the associated labour. It is developed in manufacture which cuts down the labourer into a detail labourer. It is completed in modern industry, which makes science a productive force distinct from labour and presses it into the service of capital" (Marx 1996, p. 366).

Faced with this understanding, Marx (1996, p. 367) agrees with Ferguson (1782 [1767], p. 305) according to whom "ignorance is the mother of industry as well as of superstition".

In his discussion on the application of the machinery in the modern industry, Marx returns to this point. As he explains, the machinery, instead of facilitating the labour, becomes a mean of torture, since it "does not free the labourer from work, but deprives the work of all interest [Inhalt]" (Marx 1996, p. 426). ${ }^{1}$ The ability of the machine operator, deprived of all content, is no longer relevant when the scientific knowledge is incorporated into the factory production as a power of the master.

"The separation of the intellectual powers of production from the manual labour, and the conversion of those powers into the might of capital over labour, is, as we have already shown, finally completed by modern industry erected on the foundation of machinery. The special skill of each individual insignificant factory operative vanishes as an infinitesimal quantity before the science, the gigantic physical forces, and the mass of labour that are embodied in the factory mechanism and, together with that mechanism, constitute the power of the 'master'" (Marx 1996, p. 426).

Therefore, in Marx's (1994a, 1994b, 1996) analysis of the capitalist production processes, science and technology are presented as productive powers of capital or, more specifically, as fundamental elements of the productive forces of social labour, which are dominated by capitalists against labour to conduct the production of value and surplus value. So, science and technological knowledge not only appear to be an intrinsic property of capital but also appear as the development of capital.

"Science, the general intellectual product of social development, [...] appears here as directly incorporated into capital [...] and the general development of society, because it is exploited by capital against labour,

1 The English word content, instead of interest, is a more appropriate translation of the German term inhalt adopted by Marx: "die Maschine nicht den Arbeiter von der Arbeit befreit, sondern seine Arbeit vom Inhalt" (Marx 1962, p. 446). 
because it acts as a productive power of capital over against labour, appears as the development of capital" (Marx 1994b, p. 457).

In the early twentieth century, Frederick Taylor, an engineer and manager who was not a Marxist, proposed what he called "scientific management", which presents a capitalist point of view that also corroborates the notion of polarization of information and knowledge. According to "scientific management", the deskilling of workers is a fundamental strategy to be adopted by managers and directors, who should be the sole controllers of all information and knowledge about the working processes. Taylor prescribes a fundamentalist idea of work control, recommending that managers and directors, instead of workers, should be in charge of all decisions about the production process, especially the subjective decisions. Managers should avoid situations where they become dependent on workers' initiatives and ideas. To reach this objective, all information and knowledge about the working processes dominated by workers should be collected, registered and systematized by managers and directors (Taylor 1911).

Expanding the Marxian point of view, Braverman (1998 [1974]) transposes the discussion on the role of information and knowledge onto the universe of working relations of the late twentieth century. As he explains, the fact that nowadays production has become more dependent on science and knowledge does not benefit the mass of workers. In his terms, "the more science is incorporated into the labour process, the less the worker understands the process; the more sophisticated an intellectual product the machine becomes, the less control and comprehension of the machine the worker has" (1998, p. 295).

\section{Polarization of information and knowledge within the working class}

Besides the first key argument of the polarization of information and knowledge approach, there is a second key point that sustains this perspective: information and knowledge have a fundamental role not only in the contradictions between capital and labour, but also in the contradictions within the working class.

As Braverman (1998 [1974]) argues, the detailed division of labour, deeply strengthened throughout the evolution of the capitalist mode of production, is currently present in all hierarchical levels of the companies. Thus, this division is not limited to fractioning the simple or unskilled duties conducted on the shop floor but also includes the skilled and eminently intellectual activities. Every phase of the capitalist process of production is "divorced, so far as possible, from special knowledge and training and reduced to simple labour". In this situation, the tasks of unskilled labour will occupy the mass of workers, while the relatively few workers who monopolise knowledge and skills will be freed from the duties of simple labour. Therefore, in every working process emerges a structure that "at its extremes polarizes those whose time is infinitely valuable and those whose time is worth almost nothing". This polarization within the working class can be considered the "general law of the capitalist division of labour", which "is not the sole force acting upon the organization of work, but it is certainly the most powerful and general" (1998, p. 57-58).

Contrary to the critics of Braverman's ideas, Foster (1994) explains that the author does not advocate a simplistic idea of general deskilling. Braverman does not affirm that there would be a reduction in the average skill level of workers as a consequence of capitalist development. Instead of this conclusion, he provides evidence of tendencies of increasing gaps within the working class and expanding inequalities among it. This polarization harms the majority of workers and benefits the few. In Braverman's words:

"Since, with the development of technology and the application to it of the fundamental sciences, the labor processes of society have come to embody a greater amount of scientific knowledge, clearly the "average" scientific, technical, and [...] "skill" content of these labor processes is much greater now than in the past. But this is nothing but a tautology. The question is precisely whether the scientific and "educated" content of labor tends toward averaging, or, on the contrary, toward polarization" (Braverman 1998, p. 294).

Therefore, the contradictions in the universe of labour are strengthened by the uneven access to knowledge and professional qualifications. As Rubin (1972 [1924]) puts, the long qualification periods of some professions 
and expensive learning costs constitute obstacles to the distribution of works between different sectors of social production as well as obstacles to the transference of works to different occupations. Accordingly, the high level of skills required to be admitted in some activities turns these occupations into professional monopolies.

Huws (2001) disagrees with the idea that the information and communication technologies would inexorably tend to emancipate the working class. On the contrary, the author points to an expanding gap within the contemporary workforce. On the one hand, there is a growing complexity in some working processes and some of them are becoming multi-skilled. On the other hand, other working processes have become taylorised and deskilled. Although is possible to note the emergence of new opportunities for workers, it is also possible to realize that new forms of exclusion and exploitation are rising.

The concept of the collective labourer proposed by Marx $(1994 b, 1996)$ is also an important reference for the notion of the polarization of information and knowledge. When Marx discusses the advanced capitalist production and the labour process on a large scale, he asserts that the single worker is no more the real agent of the working process. In this context, what is determinant to the production of value is the combination of multiple activities, including those that are mainly manual or unskilled and the ones that are eminently intellectual and skilled. In other words, what is relevant is the socially combined capacity to work. This aggregated work force, constituted by different individual workers, comprises the organs of what Marx terms the "collective labourer". The collective labourer is a social being composed of a complex and heterogeneous mass of individual workers with different capacities to work, qualifications and skills. Some of them have superior education and high skills, such as engineers, managers, and technicians, while others conduct mainly unskilled and manual tasks.

The category collective labourer is increasingly relevant to discuss the contemporary socioeconomic dynamics, given the growing importance of the global production chains, by means of which the production processes are fractionated and allocated in different regions across the globe. The idea of collective labourer is more insightful than the dichotomist proposition of some authors, such as Gorz (2010) and Moulier-Boutang (2011), who divide the manual activities (production) and the intellectual ones (design) into different spheres, attributing the capacity to create value only to the second type. Nevertheless, in fact every production process indispensably needs the prior phase of design, which in turn can only be realized through execution (Jeon 2012). Therefore, there is a contradictory dialectical unity between the conception of a gadget such an iPhone, conducted by some kind of labour aristocracy in Silicon Valley (United States), and the manufacturing of this apparatus in the terrible sweatshops in Shenzhen (China).

Albeit the fact that Marx's concept of collective labourer presupposes the integration between skilled and unskilled labour or, in other words, between manual and intellectual duties, his theoretical framework reveals some contradictions within the collective labourer. The Marxian analysis of the division of labour in the factories presents the engineers, mechanics, and joiners as a privileged class in comparison with the operative class: "this is a superior class of workmen, some of them scientifically educated, others brought up to a trade; it is distinct from the factory operative class, and merely aggregated to it" (Marx 1996, p. 423). In another passage, he states that, with the emergence of the collective labourer that takes place when labour assumes a social scale, the labour of the hand and of the head "part company and even become deadly foes" (Marx 1996, p. 509). Marx also returns to this point in another text where he claims the necessity to overcome the antithesis between mental and physical activities as a condition to overcome the capitalist mode of production. In his words, to build a communist society and cross "the narrow horizon of bourgeois right [...] in its entirely", it would be necessary to abolish the "the enslaving subordination of the individual to the division of labour, and therewith also the antithesis between mental and physical labour" (Marx 1989, p. 87).

If the contradictions involving information and knowledge can be considered germs for overcoming capitalism's inequality and uneven development, the effective realisation of this possibility will require the abolishment of the polarization of information and knowledge. In other words, it will require the understanding of information, knowledge and science as common goods, that is, as what Marx terms "universal labour" or "general intellect". 


\section{Towards the private appropriation of the general intellect?}

Every intellectual product is fundamentally a social product built collectively since an idea of any person is based on the ideas of his predecessors. The evolution of knowledge, science, and technology is a cumulative historical process. The statement by Isaac Newton in a letter to Robert Hooke is well known: "If I have seen further than others, it is by standing upon the shoulders of giants" (Newton 1675). ${ }^{2}$

Rarely is scientific progress the result of one sole researcher. On the contrary, science is a process developed through networks and it advances by means of a cross-pollination. Scientists learn through connections with other scientists, seeking information and inspirations within their own research fields and among distinct ones. The inspiration for new ideas has its origins in varied sources which frequently are not evident. In some cases, it is impossible to have the full consciousness of which sources were the inspiration for an innovative achievement. Even if it were possible to identify all contributors to a scientific or technological advance, it would be impossible to determine the exact quantity of each contribution (Perelman 2002).

The collective principle that characterizes the social construction of knowledge was also recognised by Marx (1996, p. 375): "A critical history of technology would show how little any of the inventions of the 18th century is the work of a single individual. Hitherto there is no such book". Thus, knowledge and scientific progress is never a product of an individual but arises from what Marx terms "universal labour" (1998) or, in the German original, Allgemeine Arbeit (1962). In his words, "universal labour is all scientific labour, all discovery and all invention. This labour depends partly on the co-operation of the living, and partly on the utilisation of the labours of those who have gone before" (Marx 1998, p. 106).

Therefore, knowledge is intrinsically a collective and communal resource, despite the fact that throughout history it has been privatized and appropriated by the ruling class at the expenses of the less privileged. As Perelman $(2002$, p. 8) notes, "a small minority of the population has become wealthy by claiming property rights to land or other goods that belonged to the community at large". As the author completes, we "should not be surprised that today, when knowledge and information are so crucial to the economy, the tradition of looting of the commons should extend to knowledge and information".

In the Grundrisse, a manuscript that can be considered a draft version of Capital, Marx (1987 [1857-1858]) perceives a future when the creation of wealth would become "less dependent upon labour time and the quantity of labour employed than [...] upon the general level of development of science and the progress of technology, or on the application of science to production". Faced with this hypothetical scenario, Marx conjectures: "as a result, production based upon exchange value collapses" (1987, p. 90-91). In other words, he presents the hypothesis of overcoming capitalism and its intrinsic logic of value through the collective knowledge, which he terms the "general intellect". So, in this brief excerpt of the Grundrisse, Marx explicitly attributes to knowledge an emancipatory power.

As predicted by Marx, currently the creation of wealth increasingly relies on the progress of science and technology, as well as on the application of science to production. Nevertheless, contradicting what Marx glimpsed about the general intellect in the Grundrisse, nowadays, the strengthening of the polarization of

2 It is worth noting that Newton is not the original author of this statement. John of Salisbury wrote in the twelfth century in his work The Metalogicon: "Bernard of Chartres used to compare us to [puny] dwarfs perched on the shoulders of giants. He pointed out that we see more and farther than our predecessors, not because we have keener vision or greater height, but because we are lifted up and borne aloft on their giant statute" (Salisbury 1955, p. 167). 
information and knowledge is evident in different contexts, at both the micro and macro socioeconomic levels. It is worth noting some examples.

Firstly, the charges to access the web are unaffordable for many people around the world, preventing the effective universalization of Internet access. Besides that, the commoditisation of the web and the evolution of the Internet governance have led to national policies that allow Internet service providers to abandon the principle of net neutrality ${ }^{3}$ in favour of zero-rating ${ }^{4}$ plans. Because of this tendency, the World Wide Web has turned into a "walled garden", especially in poor nations (Ramos 2014). A shocking result of this trend is the revelation that the majority of people in some poor and developing countries believe that "Facebook is the Internet" (Mirani 2015). So, in the realm of Internet, there is nowadays an increasing asymmetric distribution of information and knowledge.

In the sphere of world economy, the global production chains of information and communication technologies set in motion a contemporary collective labourer constituted by a heterogeneous and complex labour force that includes not only the intellectual labour aristocracy that design hi-tech apparatus, but also the Congolese slaves who extract minerals used in the IT industry, as well as the unskilled and highly exploited workers of manufacturing plants in China (Fuchs 2014; Smith 2016).

The polarization of information and knowledge is also a hallmark of some uneven education systems not only in poor countries but also in wealthy areas such as in Silicon Valley (Marques and Kerr Pinheiro 2014, 2016). In Silicon Valley, one of the most innovative places of the world, considered the "new Mecca for the high priests of high tech" (Siegel and Markoff 1985, p. 5), almost 30\% of households were living in poverty and below selfsufficiency standards in 2012. As exposed by a recent report, "nearly $30 \%$ of all Silicon Valley households do not make enough money to meet their basic needs without public or private, informal assistance" (Silicon Valley Index 2017, p. 27). The report also states that "self-sufficiency varies significantly by race/ethnicity; nearly $59 \%(81,245)$ of all Silicon Valley households with a Hispanic or Latino householder live below the SelfSufficiency Standard".

These examples reveal not only the phenomenon of polarization of information and knowledge but also some manifestations of what I term private appropriation of the general intellect. The adoption of this expression has, as a reference, Marx's (1987) discussion on the general intellect. However, it represents socioeconomic dynamics that goes in the opposite direction of what Marx had depicted in the Grundrisse. If society does not prevent the current tendency of private appropriation of crucial intangible collective goods - such as information, knowledge, and culture - humankind will be increasingly captured by the rentist logic of capitalism.

\footnotetext{
3 The net neutrality principle states that those who are responsible for providing the infrastructure of the Internet, such as telecommunications companies and Internet service providers, are not allowed to discriminate contents that circulate throughout the web. In other words, according to this principle, every content must be treated with isonomy, that is, without any discrimination based on its features such as type of content, origin or destiny, software or hardware adopted.

4 Zero-rating is a price discrimination practised by some telecommunications companies and Internet service providers by means of which they discriminate the conditions to use the global network. Zero-rated plans allow at no charges the free flow of content associated with some specific applications or services (such as Facebook and WhatsApp), while access to all other web content is conditioned to extra payments.
} 


\section{Acknowledgments}

The research was funded by the Brazilian Government (CAPES - Coordenação de Aperfeiçoamento de Pessoal de Nível Superior/Ministério da Educação e Cultura).

\section{References}

Babbage, Charles: On the Economy of Machinery and Manufactures. London: Charles Knight. 1832. Available at: <http://archive.org/details/oneconomyofmachioobabbrich>.

Braverman, Harry: Labour and Monopoly Capital. New York. Monthly Review. 1998.

Ferguson, Adam: An Essay on the History of Civil Society, 5th ed. London: T. Cadell, 1782. Available at: <http://files.libertyfund.org/files/1428/1229_Bk.pdf>.

Fetscher, Iring: Ethics. In: Bottomore, T. (Ed.), A Dictionary of Marxist Thought. Oxford: Blackwell. 1991.

Foster, John Belamy: Labor and Monopoly Capital Twenty Years After: An Introduction. Monthly Review. 46 (6), 01-13. 1994.

Fuchs, Christian: Digital Labour and Karl Marx. New York: Routledge. 2014.

Gorz, André: The Immaterial - Knowledge, value and capital. Calcutta: Seagull Books. 2010.

Huws, Ursula: The making of a cybertariat? Virtual work in a real world. Socialist Register. 37 (1), 1-23. 2001.

Jeon, Heesang: Knowledge economy. In: Fine, B.; Saad-Filho, A. (orgs.). The Elgar Companion to Marxist Economics. Cheltenham: Edward Elgar. 180-186. 2012.

Mandeville, Bernard: The Fable of the Bees or Private Vices, Publick Benefits, Oxford: Clarendon Press. 1732. Available <oll. libertyfund.org/index.php?option=com_staticxt\&staticfile=show.php\%3Ftitle=1863\&Itemid=28>.

Marques, Rodrigo Moreno and Kerr Pinheiro, Marta Macedo: Polarização do conhecimento na era da informação - O Vale do Silício como exemplo. Tendências da Pesquisa Brasileira em Ciência da Informação. 7 (1), 1 20. 2014. Available at: <http://inseer.ibict.br/ancib/index.php/tpbci/article/view/125>.

Marques, Rodrigo Moreno and Kerr Pinheiro, Marta Macedo: Cognitive capitalism or polarization of knowledge? Voices from Silicon Valley unveil myths of the information age. In: III Journées Scientifiques Internationales du Réseau Franco-Brésilien de Chercheurs en Médiations et Usages Sociaux des Savoirs et de I'Information (MUSSI), Toulouse (France): ENFA, v. III, p. 155-172. 2016.

Marx, Karl: The future results of British rule in India. New-York Daily Tribune. No. 3840. August 8, 1853. Available at: <https://www.marxists.org/archive/marx/works/1853/07/11a.htm>.

Marx, Karl: Das Kapital. Band I - Kritik der politischen Ökonomie, Erster Band, Buch I. In: Marx, K.; Engels F. Werke Band 23, Berlin: Dietz Verlag. 1962.

Marx, Karl: Economic Works 1857-1861: Economic Manuscripts of 1857-1858 (Grundrisse). In: Marx, K.; Engels, F. Collected Works, v. 29, London: Lawrence \& Wishart. 1987.

Marx, Karl: Critique of the Gotha Programme. In: Karl Marx and Friedrich Engels. Collected Works, v. 24, London: Lawrence \& Wishart. 1989.

Marx, Karl: Economic Works 1861-1864. Economic Manuscript of 1861-1863 (Theories of Surplus Value). In: Marx, K.; Engels, F. Collected Works, v. 34, London: Lawrence \& Wishart. $1994 a$.

Marx, Karl: Economic Works 1861-1864 (Chapter Six - Results of the Direct Production Process). In: Marx, K.; Engels, F. Collected Works, v. 34, London: Lawrence \& Wishart. $1994 b$.

Marx, Karl: Capital - A Critique of Political Economy - Volume I. In: Marx, K.; Engels, F. Collected Works, v. 35, London: Lawrence \& Wishart. 1996.

Marx, Karl: Capital - A Critique of Political Economy - Volume III. In Karl Marx and Friedrich Engels, Collected Works, v. 37, London: Lawrence \& Wishart. 1998. 
Mirani, Leo. Millions of Facebook users have no idea they're using the internet. Quartz, February 2015. Available at: <https://qz.com/333313/milliions-of-facebook-users-have-no-idea-theyre-using-the-internet>.

Moulier-Boutang, Yan: Cognitive Capitalism. London: Polity Press, 2011.

Newton, Isaac: Letter to Robert Hooke, 1675. Available at: <http://digitallibrary.hsp.org/index.php/Detail/Object/Show/object_id/9285>.

Perelman, Michael: Steal this idea - Intellectual Property Rights and Corporate Confiscation of Creativity. New York: Palgrave. 2002.

Ramos, Pedro Henrique Soares: Towards a developmental framework for net neutrality: the rise of sponsored data plans in developing countries. 2014 TPRP Conference Paper. 2014. Available at: <http://ssrn.com/abstract=2418307>.

Rubin, Isaak Illich: Essays on Marx's Theory of Value, Detroit: Black and Red. 1972.

Salisbury, John of: The Metalogicon. London: Cambridge University Press, 1955.

Siegel, Lenny and Markoff, John: The High cost of high tech - The dark side of the chip. New York: Harper \& Row, 1985.

Silicon Valley Index 2017. Available at: <http://www.jointventure.org/download-the-2017-index>.

Smith, John: Imperialism in the twenty-first century. New York: Monthly Review Press, 2016.

Taylor, Frederick Winslow: The Principles of Scientific Management, Nova York: Harper \& Row. 1911. 